such republication. He said very positively that he did not. In so far, however, as we are concerned, we are perfectly willing that you should reprint this article, provided only you publish in an equally conspicuous place. the following statement. As shown by the records of the Health Offe of Cleveland, Ohio, Dr. Martin Friedrich was appointed health officer during a waning epidemic of small-pox. He at once, and very properly, began to clean up the infected districts. The last cases soon disappeared, but previous to his campaign their numbers were becoming fewer and fewer. In a very short time the disease was again introduced into Cleveland from without. In spite of the previous disinfections and their vigorous continuance in the new epidemic, the number of cases inereased month by month. At first, during the spring and summer with increasing numbers of cases, general vaccination was not introduced on account of Dr. Friedrich's unwillingness to use an unsatisfactory vaccine. Finally, however, a satisfactory virus was secured and general vaccination was hegun. The workmen in numerous shops, children about to re-enter school for the fall term, and all persons who came in contact with small-pox were vaccinated as rapidly as possible. Within two months after the beginning of general vaccination an epidemic which had promised by its constantly increasing numbers of cases to be very serious indeed began to decline and once on the decline dropped off with great rapidity. You will please note that in the above statement there can be found scarcely a please note that in the above statement there can be found scarcely a ingle statement of opinion, simply cold, hard facts. We presume that these lacts are the reason wh Dr. Friedrich declines to have his paper epubised, though here, can only grant publiss the above statement, and thank you very much for not having published it without permission.

$$
\begin{aligned}
& \text { Sincerely yours. } \\
& \text { (Signed) The Cleteland MedicaI. JouRnal. }
\end{aligned}
$$

In this letter permission was given to make use of Dr. Friedrich's article provided only the statement contained in the last half of our letter be published in an equally conspicuous space. In the brochure before us the first six and one-half pages have been abstracted from Dr. Friedrich's article and no allusion has been made in this place to our letter quoted above. Not until we reach p. 175 of the brochure do we find our statement of the facts and in this way the compiler has violated the conditions under which permission for republication was granted.

It is deeply to be regretted that the Cleveland Medical Journal should have been in the smallest degree available as a source of material for the propaganda of the antivaccinationists. We are delighted to be able to report that during the last four years, under the efficient management of Dr. Friedrich, our health officer, aided by a corps of district physicians, vaccination has been carried out in a most thorough manner with the happy result that Cleveland has been during this time practically free from small-pox. At the present time it is the rule of our health office that no child shall be allowed to return to the public schools without having been first properly vaccinated. Trusting that you will be able to give this communication the prominence which it seems to us to deserve,

We remain, yours very truly,

The Clevel aNd Medical Journal, Edward Perkins Carter, Editor.

Cleveland, U.S.A., Sept. 26th, 1906

\section{PURIN-FREE DIETS.}

\section{To the Editors of THE LANCET.}

SIRs,-In his interesting article on the above subject in The LANCET of Oct. 6th Dr. W. A. Potts says: "The condition of 'hyperpyræmia,' due to an excess of caroohydrates, recently described as the underlying element in many disorders, is not developed on a properly arranged fruitarian diet; all excesses are bad and too much starchy (carbohydrate?) food in conjunction with meat is especially bad." I fully agree with the whole of this statement. Indeed, would go further and admit that a properiy arranged fruitarian diet is in many cases capable of dispersing the condition of hyperpyræmia and the numerous disordersmigraine, asthma, and other recurrent affections less well defined-which I have claimed are very commonly dependent thereon. In treatment by such a diet the hyperpyramia is dispersed by means of the necessary reduction in the proteid intake.

But why cease from clinical experiment at this stage of the argument? Why nut take a series of similar cases and try the effect of striking out the other factor in the injurious food combination-namely, the carbohydrate excess? The experiment is simple, harmless, and, when restricted to patients who are more or less corpulent, almost always successful. All that is needful is to cut off sugar, including articles of food containing sugar, and reduce the remainder of the purely carbonaceous intake-fats and starches, especially the latter-to the level at which the patient is slowly losing weight. Even a less severe reduction is often sufficient. When this is done, many recurrent affections, such as bilious attacks, sick headaches, asthma, and even some cases of angina pectoris, cease at once; and many chronic affections, such as persistent bronchial catarrh and the so-called gouty eczema and pruritus, steadily improve and disappear in the course of a very few weeks.

But if this is true-and the statement may be readily verified by every practitioner of medicine-what becomes of the contention that the purin intake is an essential factor in any of the affections mentioned? Meat, both red and white, of necessity enters largely into the dietary of such patients and tea, coffee, meat extracts, and other purin foods may be given freely without danger of inducing relapse, so long as the purely carbonaceous intake is adequately restricted. On the other hand, as Dr. Potts himself has stated, "the mere fact that a diet is purin-free is of little value."

I am, Sirs, yours faithfully,

Upper Norwood, S.E. Francis HaRe.

\section{CERTAIN ANALOGIES BETWEEN IN- FLUENZA AND PULMONARY}

\section{TUBERCULOSIS.}

To the Editors of THE LANCET.

Sirs,-I would be much obliged by your publishing the following note. In THE LANCET of Sept. 15th I have noticed a misprint which makes the paragraph in which it occurs somewhat difficult to understand. I refer to your account of the paper that I read in the Section of State Medicine at the Toronto meeting of the British Medical Association. The fourth general analogy between tuberculosis and influenza that I undertook to discuss was described in the abstract of the paper which it is usual to furnish beforehand in the following words : Both distinctly affect the functions of relation $(a)$ by exciting rheumatic symptoms-infections rheumatism in the one case, rhumatisme tuberculeux (Poncet) in the other; and (b) by giving rise to meningeal and other nervous complications.

The misprint to which I refer, it will be seen, makes this meaning obscure.

1 am, Sirs, yours faithfully,

Nice, Oct. 5th, 1906.

A. W. Gilchrist, M.D. Paris.

\section{PRESCRIBING BY OPTICIANS.}

\section{To the Editors of THE LANCET.}

SiRs, - I beg to inclose for your perusal a page from a copy of the Optician and Photographio Trades Revien sent to me presumably in the ordinary course of advertisement from the offices of the paper. The reply to an "Assistant" (save the mark!) shows what considerable advances the technical education of "optologists" is making when such advice is tendered to assistants. I have during the last few months had the following cases through my consulting-room. Two of hemianopsia with cerebral tumour, since dead, both losing six months of invaluable medi cinal opportunity, whilst having spectacles provided and changed, \&c., by opticians whom they had unfortunately consulted; one of diabetic cataract nine months under an optician with three changes of expensive spectacles; one of optic atrophy five months under an optician with three changes of spectacles. One lady whom I operated upon for cataract (double-could not count fingers with either eye) was four months before carefully examined by an optician "in a dark room" and solemnly assured that there was nothing the matter with her eyes but that her pride was preventing her from wearing the necessary spectacles, \&c. Surely it is about time that the question was settled whether it were not better for ophthalmic surgeons to become opticians as well in order, if possible, to protect the public from the educated incapacity of this spreading charlatanism. Sept. 28th, 1906 I am, Sirs, yours faithfully,

FrFE.

\section{THE TREATMENT OF INEBRIETY. \\ To the Editors of THE LANCET.}

SIRE,-A difficulty frequently experienced in the medical treatment of inebriety is the aversion so many inebriates have to water, whether cold, hot, or aerated. They are more or less thirsty and desire something to drink with their meals-but not water. It has been my lot to treat a very large number of drunkards within the last few jears, nearly 